\title{
Response of Native Grassland Legumes to Water and Nitrogen Treatments
}

\author{
W.K. LAUENROTH AND J.L. DODD
}

\begin{abstract}
The response of native shortgrass prairie legumes to water and nitrogen additions was evaluated utilizing a replicated factorial design of two water and two nitrogen treatments. Responses measured were densities and aboveground biomass by species. Water treatment greatly increased both density and biomass of legumes, presumably because of more favorable conditions for nitrogen fixation and increased competitive advantage under nitrogen deficient conditions.
\end{abstract}

The availability of nitrogen, more than any other mineral element, is a critical determinant of both the structure and productivity of grassland plant communities (Date 1973). Additionally, mineral nitrogen supplies to the plant community largely determine the value of the biomass produced as forage for consumers. In native grasslands nitrogen-fixing plants are presumed to occupy an important position in nitrogen cycling although for most grasslands very little is known about the ecology or functional significance of native legumes (Becker and Crockett 1976). This is particularly true of the semiarid grasslands of the Great Plains of North America. The majority of the information available concerning the ecology of legumes in these grasslands is available as an incidental portion of the data collected on the dominant grassland plants (Albertson 1937; Hanson and Whitman 1938; Dyksterhuis 1946; Brown 1971; Hyder et al. 1975).

As a first step in understanding the functional role of legumes in a shortgrass prairie, we provide basic phytosociological data for legumes under ambient environmental conditions and results from experimental manipulation of soil water and mineral nitrogen availability.

\section{Methods}

\section{Site Description}

The Pawnee Site ${ }^{1}$ is located in northeastern Colorado approximately $61 \mathrm{~km}$ northeast of Fort Collins. The climate of the region is temperate semiarid receiving approximately $310 \mathrm{~mm}$ of annual precipitation. The cight experimental plots were located within an exclosure on an Ascalon sandy loam soil.

The vegetation of the area is characterized by the predominance of the shortgrass blue grama [Bouteloua gracilis (H.B.K.) Lag.]. ${ }^{2} \mathrm{Im}-$

\footnotetext{
The authors are ecologists, Natural Resource Ecology Laboratory, Colorado State University. Fort Collins. Colorado 80523

This paper reports on work supported in part by National Science Foundation Grants GB-7824, GB-13096, GB31862X, GB-31862X2. and GB-41233X to the Grassland Biome, U.S. International Biological Program, for ${ }^{*}$ Analysis of Structure, Function, and Utilization of Grassland Ecosystems.

Manuscript received March 24, 1978.

I The field research facility of the Natural Resource Ecology Laboratory. Colorado State University. Fort Collins. located on the Central Plains Experimental Range which is administered by the USDA Science and Education Administration, Agricultural Research.

2 Nomenclature follows Harrington (1954).
}

portant associated species include fringed sagewort (Artemisia frigida Willd.) and plains pricklypear (Opuntia polyacantha Haw.).

\section{Experimental Design}

The experiment was initiated in 1970 utilizing a replicated factorial design of two water and two nitrogen treatments. Each of the two replicates included four 1-ha plots consisting of a control, water, nitrogen, and water plus nitrogen treatments.

The nitrogen treatment criterion was to maintain a difference of at least $50 \mathrm{~kg} \mathrm{ha}^{-1}$ of mineral nitrogen $\left(\mathrm{NH}_{4}^{+}+\mathrm{NO}_{3}^{-}\right)$between the control and the nitrogen treated plots. This was accomplished by spring applications of ammonium nitrate fertilizer as necessary based upon soil nitrogen analyses. The water treatment consisted of maintaining soil matric potential at a depth of $10 \mathrm{~cm}$, above -.08 bars during the May to September growing season. Matric potential was maintained within the treatment range by nightly applications of water with a solid set sprinkler system and monitored by ceramic tensiometers. Although the experiment was begun in 1970, the water treatment criterion was not satisfactorily met until 1971 .

\section{Legume Biomass and Density}

Aboveground biomass (live + attached dead) was collected on eleven dates in 1970, three dates in 1971, nine dates in 1972, and six dates in both 1973 and 1974 . In 1970 ten $0.25-\mathrm{m}^{2}$ quadrats were harvested at ground level for each treatment on each date. During the remaining years twelve $0.50-\mathrm{m}^{2}$ quadrats were harvested for each treatment on each sample date.

Numbers of individuals of each species occurring within one hundred $0.25-\mathrm{m}^{2}$ quadrats per treatment were recorded on approximately July 1 in each year from 197I through 1974.

\section{Results}

Water is clearly an important factor limiting legume populations in shortgrass prairies (Fig. 1). Initial densities of legumes ranged around $1 \mathrm{~m}^{-2}$ for all three treatments and the control (Table 1). Densities remained less than $\mathrm{I} \mathrm{m}^{-2}$ for the nitrogen treatment and the control throughout the 4 years of study. Legume density on the water plus nitrogen treatment increased dramatically during the second year of treatment presumably as a result of the favorable growing conditions produced by this treatment. The decreases in density observed during the last 2 years on the water plus nitrogen treatment were very likely the result of increased competition from species better able to utilize the elevated levels of water and mineral nitrogen. The poor competitive ability of legumes in pastures fertilized with mineral nitrogen is well established (Templeton 1976). Density of legumes on the water treatment increased in each year of the study and in 1974 was approximately 30 times greater than the control.

A total of seven species of legumes were encountered throughout the study period; the largest number of these was 
The clear sensitivity of nitrogen fixation to water availability (Vincent 1965) raises serious questions about the potential contribution of legumes to the nitrogen economy of semiarid grasslands. Reuss (1971) in a preliminary investigation of the role of symbiotic nitrogen fixation in a shortgrass prairie concluded legumes probably contributed less than $1 \mathrm{~kg} \mathrm{ha}^{-1}$ to the annual nitrogen balance. Although this is a very small amount of nitrogen, it did account for $20 \%$ of the total annual inputs. Woodmansee (1978) presented a more pessimistic view of the potential inputs of nitrogen from symbiotic fixation for six semiarid and arid grasslands, indicating an average of less than $0.5 \mathrm{~kg} \mathrm{ha}^{-1}$ year $^{-1}$ for each site. For a shortgrass prairie this amounted to $7 \%$ of his estimate of total annual input. Reuss (1971) attributed the small contribution of nitrogen by symbiotic fixation to small populations of legumes and the short duration of conditions favorable for nitrogen fixation.

Additions of water to the shortgrass prairie changed these circumstances significantly. Increased availability of soil water for the entire growing season dramatically increased the size of the legume population and presumably also resulted in much more favorable conditions for nitrogen fixation. Utilizing Reuss's (1971) figures for fixation rates of various species, calculated nitrogen fixation for the water treatment ranged from less than $1 \mathrm{~kg} \mathrm{ha}^{-1}$ year $^{-1}$ in the 1970 to $18 \mathrm{~kg} \mathrm{ha}^{-1}$ year $^{-1}$ in 1973.

The above estimates assume that legumes are the only $\mathrm{N}$-fixing species in the community although there is some evidence that other species may fix nitrogen symbiotically, particularly fringed sagewort and plains pricklypear (Porter 1969). If we assume that legumes are the most active nitrogenfixers in the shortgrass prairie, the large increase as a result of supplemental watering suggests a balance between nitrogen fixation and soil water availability. Masefield (1958) found that wet soil conditions resulted in high nodulation of legumes. Although our data are far from conclusive evidence, the general trends lead us to the conclusion that the legumes on the water treatment will continue to increase until enough nitrogen is being fixed so that the population of legumes will be limited by competition from the remainder of the community. An analo- gous situation has been reported in pasture mixtures of grasses and legumes (Blaser and Brody 1950; Templeton 1976). Increased nitrogen availability either by fertilization or nitrogen fixation intensifies competition between grasses and legumes.

\section{Literature Cited}

Albertson, F.W. 1937. Ecology of mixed prairie in west central Kansas. Ecol. Monogr. 7:481-547.

Becker, D.A., and J.J. Crockett. 1976. Nitrogen fixation in some prairie legumes. Amer. Midl. Natur. 96:133-143.

Blaser, R.E., and N.C. Brody. 1950. Nutrient competition in plant associations. Agron. J. 42:128-135.

Brown, R. 1971. Distribution of plant communities in southeastern Montana badlands. Amer. Midl. Natur. 85:458-477.

Date, R.A. 1973. Nitrogen: A major limitation in the productivity of natural communities, crops and pastures in the Pacific area. Soil Biol. Biochem. 5:5-18.

Dyksterhuis, E.J. 1946. The vegetation of the Fort Worth prairie. Ecol. Monogr. 16:1-3I.

Hanson, H.C., and W.C. Whitman. 1938. Characteristics of major grassland types in western North Dakota. Ecol. Monogr. 8:57-114.

Harrington, H.D. 1954. Manual of the Plants of Colorado. Swallow Press Inc., Chicago. 666 p.

Hyder, D.N., R.E. Bement, E.E. Remenga, and D.F. Hervey. 1975. Ecological responses of native plants and guidelines for management of shortgrass range. U.S. Dep. Agr. Tech. Bull. No. 1503. 87 p.

Masefield, G.B. 1958. Some factors affecting nodulation in the tropics. p. 202215. In: E.G. Hallsworth (Ed.) Nutrition of Legumes. Butterworths, London.

Porter, L.K. 1969. Nitrogen in grassland ecosystems. p. 377-402. In: R.L. Dix and R.G. Beidleman (Eds.) The Grassland Ecosystem: A Preliminary Synthesis. Range Sci. Dep. Sci. Ser. No. 2. Colorado State Univ., Fort Collins.

Reuss, J.O. 1971. Decomposer and nitrogen cycling investigations in the Grassland Biome. In: N.R. French (Ed.) Preliminary Analysis of Structure and Function in Grasslands. Range Sci. Dep. Sci. Ser. No. 10. Colorado State Univ., Fort Collins.

Templeton, W.C., Jr. 1976. Legume nitrogen versus fertilizer nitrogen for cool-season grasses. p. 35-54. In: Biological N Fixation in Forage-Livestock Systems. ASA Special Publication No. 28. Amer. Soc. Agron., Madison, Wisc.

Vincent, J.M. 1965. Environmental factors in the fixation of nitrogen by the legume. p. 384-435. In: W.V. Bartholomew and F.E. Clark (Eds.) Soil Nitrogen, Agronomy 10. Amer. Soc. Agron., Madison, Wisc.

Woodmansee, R.G. 1978. Nitrogen dynamics in grassland ecosystems: Additions and losses. BioScience 28:448-453.

\section{Rangeland Entomology}

Rearrangement of a storage area has uncovered an additional carton of Rangeland Entomology and approximately 200 copies are now available. This second of the Range Science Series, by Hewitt, Huddleston, Lavigne, Ueckert, and Watts, is available for \$2.25 from the Society for Range Managment, 2760 West Fifth Avenue, Denver, Colorado $802(04$. 